\title{
The Impact of Suggested e-Activities via Social Networks on Improving the Linguistic Skills of Arabic Speakers of Other Languages
}

\author{
Basmah Issa Ahmad AlSaleem \\ TEFL Associate Prof. \\ The World Islamic Sciences and Education University \\ Amman, Jordan
}

Doi: 10.19044/ejes.v5no2a4

URL:http://dx.doi.org/10.19044/ejes.v5no2a4

\begin{abstract}
This study investigated the impact of using suggested e-activities via social networks (Facebook) in enhancing linguistic skills (reading comprehension skills) for Arabic Language learners who speak other languages in the Arabic for Speakers of Other Languages Centre at The World Islamic Sciences and Education University, Jordan. Participants of the study were Arabic Language learners who speak other languages who come to Jordan from different foreign countries to learn Arabic language. The researcher hypothesized that if these learners practiced e-activities via Facebook, their reading comprehension skills may be improved. For answering questions of the study, the researcher designed a pre-post reading comprehension skills test to determine the participants' mastery for reading comprehension skills. Furthermore, she uploaded the e-activities on a Facebook account that were made available for all the participants of the study. Results revealed that the suggested e-activities via social networks media (Facebook) were effective in improving participants' reading comprehension skills. Then the study recommended that social networks media could be utilized in improving other skills such as speaking and listening.
\end{abstract}

Keywords: Social Networks, E-activity, Linguistic skill, Arabic language, Learners, Speak other Languages.

\section{Introduction and Background}

Listening, speaking, reading and writing are the essential skills in every language but other researchers add another advanced skill such as literary appreciation. Furthermore, they entail main sub skills. Recent decades witnessed huge changes in teaching reading through the whole world because of results of modern studies and researches. The ability to comprehend written 
material is the main factor in academic success for learners, as it eases understanding other subjects (Awartani,2006).

Arabic language learners who speak other languages face difficulties and obstacles in their achievement and success. Furthermore, these difficulties result in weakness in direct comprehension and failure in Arabic learning (AlZayat,1998). One of the essential factors that hinder learning Arabic language is linguistic problems and changes in mother tongue, voices, utterances and even tongue. For example, those students who come from Korea, Japan, China and other countries face difficulty in pronouncing and reading Arabic language because of the change of pronunciation and also in their mother tongues, so Chinese learners face weakness in that field except others (AlQamati,1986).

Another reason relies to Arabic language learners who speak other languages, is that they can not read the Holy Quran easily because they do not read Allah's Holy Book and the Prophetic Sunnah. In addition, there are problems concerning utterances for Arabic sounds such as sounds of throat (the highest throat, the middle throat and lowest throat).

الهمزهو الهاءو الحاء و العين و القاف و الكاف و الخاء و الغين

So learners get confused and pronounce Alein into Hamzah, Alghein into GHaa, and Alqaaf into Kaaf. Furthermore, foreigner students listen to voices and sounds which he/she did not hear or pronounce before so they face and experience different kinds of syllables, toning and soundtracks and even audio listening devices did not use to manipulate them, then these kinds of learners face difficulties in pronunciation and reading,(Abdullah,2007).

Through reviewing literature in the field of teaching Arabic linguistic skills for Arabic language learners who speak other languages, it becomes apparent that these learners experience low levels in practicing these skills. One of the prominent authors is Toeima. He was interested in the field and clarifying methods utilized in this branch of teaching and learning for Arabic language learners who speak other languages. Also, it depends on Arabic and foreign studies preceded it and many authors contributed in stating linguistic skills for those who speak Arabic and non-Arabic speakers, (Toeima,1984).

As Arabic structure of syllables is simple, its vocabulary constitutes of simple syllables that disconnects between its consonants and vowels, the relationship between letters and diacritics of the language and its sound is clear and steady because the letter in Arabic language represents a single sound not many sounds as in many languages such as English language (cat, car, call, care). For all these reasons, the ability for accepting accurate and quick reading is easy and fast as in other similar languages (Aro \& Wimmer, 2003; Seymour,2003) This, also, happens in reading multi-syllable vocabulary or even long meaningless vocabulary (Saiegh-Haddad \& Geva, 2008). 
The Arabic alphabetic form is recognized via orthographic clarity (Liberman et al. 1980) this means that the relationship between vocabulary shape and its pronunciation is clear and stead. So, this advantage contributes rapidly in pronouncing vocabulary in one context but in another context, it contributes greatly in the strategy of voice structure with tremendous effectiveness (Al Mannai \& Everatt, 2005).

As for reading sub-skills; it means identifying written symbols, comprehending, interpreting, criticizing and utilizing what these symbols indicate. Learning reading follows listening and speaking but other scholars mentioned that it follows listening skill, (AlNaqa,1983)

Through reviewing some of researches, reading purposes can be summarized as following;

1- Pronouncing the text correctly even it is aloud or silent reading.

2- Comprehending the text and subtracting its general ideas.

3- Mastering the word in aloud reading efficiently and speedy in silent one.

4- Mastering comprehension via interpreting and analyzing.

5- Criticizing and assessing, (Elayan,1982).

Reading through practicing is divided into two types: Silent reading; Via this kind the reader depends on his eyes and mind only as he looks at the text and grasps what he reads in his mind without pronouncing or whispering or even moving his tongue or lips (Stanovich, 2000). Furthermore, this kind is quick and it is needed in life for achieving goals and it is required for comprehending and grasping as there is no effort for pronunciation or its restriction, (Abdullah,2012). Aloud reading; means changing written symbols into sound symbols through pronouncing with proper practices and utterances. This type consumes time more than silent one, via it, learners could earn correct pronunciation and impressive practices and has its needs that affect it, ( Madkour,2006).

Concerning reading skills, the recent study utilized only five of them to be enhanced for Arabic language learners who speak other languages;

1- Recognizing new meanings for one word.

2- Recognizing new words for one meaning.

3- Classifying words according to synonyms and antonyms.

4- Extracting ideas through written texts.

5- Determining general meaning via reading texts, (AlHallaq,2010).

6- Considering learning reading, $\operatorname{Kang}(2008)$ has provided evidence that learners involved in the e-reading process can be more accurate in their comprehension abilities than they are while using traditional reading methods. Kang found that e-learners might require more time than learners using traditional media in order to break down and analyze e-texts; however, their accuracy in 
locating specific information was superior to learners using paper versions containing the same information. In this case, they argue that online reading comprehension is higher than traditional reading comprehension.

So, the recent study tries to utilize using suggested e-activities via social networks media specially to improve linguistic skills, specifically reading comprehension, for Arabic language learners who speak other languages.

For surfing previous studies about reading on the internet, the researcher did not find Arabic studies in the field of teaching Arabic for Arabic language learners who speak other languages. On the contrary, she found studies that improved EFL reading skills such as Hamed's (2016) study which utilized web-based reading MOODLE to enhance reading comprehension skills for the third year reparatory institute pupils. In the same track, she found other studies that utilized social media in improving other skills such as (Al.Omdah,2017) who utilized Facebook and Twitter in improving social oral skills via A MOODLE.

In the age of internet, social interaction and engagement has evolved. Social media has become an integral avenue of social interaction. Given that engagement with peers is an important component to student success in higher education (Thalluri, 2014), Contemporary teaching methods have been adapted to include social media, specifically the Facebook, a very popular networking website amongst all age groups. In order to maximise the potential of Facebook for collaboration and interactivity, various universities have attempted to incorporate it in their learning and teaching approaches. Education, medicine, pharmacy, medical radiation, veterinary students and library users have reported using Facebook in learning (Ellison, 2007; Cain, 2008; Thompson, 2008).

The real and potential benefits of Facebook are documented. It presents a relaxed, accessible, friendly and comfortable environment that promotes collaboration, social exchange of knowledge/ideas, and student engagement in learning outside the classroom (Hendrix, 2009). In the same track, technologies used in learning may promote a social constructivist educational approach which is student focused, highlighting open dialogue and collaborative construction of knowledge (Whittaker, 2013).

On the other hand, the educational benefits of Facebook were researched by many scholars. For example, Hew (2011) concluded that there are very much educational values and that their applications are not limited to staying connected with others. Wise (2011) corroborated this view and mentioned that Facebook promotes social and academic engagement. Furthermore, this new digital paradigm is changing how we relate to society. 
In the midst of proliferating social connected devices and websites, there are feelings of isolation and loneliness (Madden, 2013).

The need to provide guidelines for its use is actually stated for university students who already use platforms as they are accessible, quick and convenient, and there is a real potential for its application on learning and teaching provided that it is carefully and appropriately structured (Ponce, 2013). Some researchers such as Gabal (2017) utilized activities-based on social networking sites in enhancing social oral skills for Arabic language learners who speak other languages in al-Azhar University who come from different Islamic countries

\subsection{Problem Statement}

Through reviewing the literature, it becomes apparent for the researcher that a great number of researchers dealt with social media and others dealt with linguistic skills stated in reading comprehension. In the same trend, the researcher noticed that Arabic language learners who speak other languages have lowness in linguistic skills. So, she strengthened the sense of the problem. A pilot study was carried out, by the researcher, for a sample of ASOL Center WISE University .The results are shown in Table 1 below:

Table 1

The Students' Achievement Level on the Reading Comprehension Test

\begin{tabular}{|l|l|l|l|l|l|l|}
\hline & $\begin{array}{c}\text { Syllable } \\
\text { read } \\
\text { ing }\end{array}$ & $\begin{array}{l}\text { Vocabulary } \\
\text { reading }\end{array}$ & $\begin{array}{l}\text { Sentence } \\
\text { reading }\end{array}$ & $\begin{array}{l}\text { Identifying } \\
\text { specific } \\
\text { information }\end{array}$ & $\begin{array}{l}\text { Predicting } \\
\text { outcome }\end{array}$ & Total \\
\hline Test marks & 7 & 9 & 10 & 8 & 6 & 40 \\
\hline Mean & 6.9 & 7.2 & 2.82 & 5.88 & 2.36 & 25.16 \\
\hline Percentage & $69 \%$ & $80 \%$ & $47 \%$ & $73 \%$ & $39 \%$ & $\begin{array}{l}67.69 \\
\%\end{array}$ \\
\hline
\end{tabular}

Results in table (1) indicate that the sample's mean score on the reading comprehension test is below the average score (50\%). So, results indicate that the students' achievement in reading comprehension is weak. This showed that students lacked the necessary skills to handle the reading passage. Therefore, it was essential to study this problem and find a proper treatment in order to provide the learners with the basic skills to deal with the text they handle for better achievement and pleasure. Therefore, the researcher suggested utilizing e-activities via social networks media to improve linguistic skills (reading comprehension) for Arabic language learners who speak other languages.

\subsection{Questions}

In order to tackle the problem of students who lacked the necessary skills to handle the reading passage, the present study attempted to answer the following main questions: 
What is the impact of using e-activities via social networks media to improve the reading comprehension skill for Arabic language learners who speak other languages?

For research purposes this main question can be subdivided into the following sub-questions:

1. What are the required reading comprehension skills for Arabic language learners who speak other languages?

2. How far do the Arabic language learners who speak other languages master reading comprehension skills?

3. What are the features of using e-activities via social networks media to improve the reading comprehension skill for Arabic language learners who speak other languages?

4. What is the impact of the suggested e-activities via social networks media to improve the reading comprehension skill of Arabic language learners who speak other languages?

\section{Methodology}

\subsection{Design}

The current study employed the quasi-experimental design in terms of dividing the participants of the study into two groups, an experimental group and a control group. The experimental group was taught using the suggested e-activities via social networks media (Facebook) but the control group was taught via the traditional method.

\subsection{Purposes}

This study attempted to:

1. Identify the reading comprehension skills necessary for Arabic language learners who speak other languages.

2. Assess the current level of Arabic language learners who speak other languages in the identified reading comprehension skills.

3. Determine the effectiveness of using the suggested e-activities via social networks media to improve the reading comprehension skill of Arabic language learners who speak other languages.

\subsection{Community and participants}

For the purpose of the study, the foreign students at the Arabic for Speakers of Other Languages Centre of Languages at WISE University were chosen from the Jordanian Universities. 


\subsection{Delimitations}

This study was limited to:

1. A sample of the Arabic language learners who speak other languages in the Center of Languages at Yarmouk University.

2. Some linguistic skills (reading comprehension skills) were utilized for Arabic language learners who speak other languages.

\subsection{Instruments}

The researcher used the following instruments to tackle the problem of the study:

1. A reading comprehension skills questionnaire to determine the most important reading comprehension skills for the Arabic language learners who speak other languages.

2. A pre-post reading comprehension skills test for the Arabic language learners who speak other languages designed by the researcher to assess participants' skills.

\subsection{Program}

It was a collection of e-activities uploaded on Facebook account to develop reading comprehension skills.

\subsection{Study Importance}

Few studies have been conducted in the same track in general, and on the reading comprehension skills in particular. There has also been only limited research in the Arabic context in general, and in the Jordanian context in particular. Therefore, the current research is unique since it examines the impact of suggested e-activities via social networks (Facebook) to improve the reading comprehension skills for Arabic language learners who speak other languages.

\subsection{Procedures}

In order to answer the questions of the study, the study proceeded according to the following steps:

1. Reviewing the literature and the previous studies related to the features of e- activities, social networks (Facebook) linguistic skills (reading comprehension) for Arabic language learners who speak other languages.

2. Randomly choosing the sample of the study and dividing it into an experimental group and a control group.

3. Designing, the pre-post reading comprehension skills' tests then presenting them to a jury for verifying their validity and suitability for the sample. 
4. Identifying and modifying the most appropriate items of the pre-post reading comprehension skills' tests according to the jury's panel opinions and using only one test.

5. Applying the aforementioned test to determine its reliability.

6. Administering the above mentioned test as pre administration for both the experimental group and the control group.

9. Designing the Facebook e-activities and presenting them to a jury to identify their suitability of them for the reading comprehension skills, participants' level and the aims of the program in general.

12. Modifying the program according to the jury's opinions.

13. Conducting the program to the experimental group on Facebook and conducting the same program for the control group via regular method.

14. Administering the above mentioned test as post administration for both the experimental group and the control group after the program.

15. Scoring and treating the data statistically.

16. Presenting summary, results, conclusion, and recommendation.

\section{Results}

The researcher used the SPSS statistical package to calculate means, standard deviation of the score. The " $t$ " test was used to determine differences between the mean scores of the students in both groups on the pre-post reading comprehension test.

For answering questions of the study, the t-test for independent and dependent groups was used. Results are shown in Table 2,below:

\section{Table 2}

T-Test of the Post Administration of the Pre-Post Reading Comprehension Test Comparing the Experimental and the Control Groups

\begin{tabular}{|c|c|c|c|c|c|c|c|}
\hline \multirow{2}{*}{ Reading Test Dimensions } & \multirow{2}{*}{ Groups } & \multirow{2}{*}{$\mathbf{N}$} & \multirow{2}{*}{ Mean } & \multirow{2}{*}{ S. Deviation } & \multicolumn{3}{|c|}{ T-test for Equality of Means } \\
\hline & & & & & $\mathrm{t}$ & $\mathrm{df}$ & Sig. \\
\hline \multirow[b]{2}{*}{$\begin{array}{l}\text { Recognizing new meanings for } \\
\text { one word. }\end{array}$} & Experimental & 40 & 2.15 & .533 & \multirow[b]{2}{*}{5.807} & \multirow[b]{2}{*}{78} & \multirow[b]{2}{*}{.05} \\
\hline & Control & 40 & 1.48 & .506 & & & \\
\hline \multirow{2}{*}{$\begin{array}{l}\text { Recognizing new words for } \\
\text { one meaning. }\end{array}$} & Experimental & 40 & 2.18 & .636 & \multirow[b]{2}{*}{4.133} & \multirow[b]{2}{*}{78} & \multirow[b]{2}{*}{.05} \\
\hline & Control & 40 & 1.55 & .714 & & & \\
\hline \multirow{2}{*}{$\begin{array}{l}\text { Classifying words according to } \\
\text { synonyms and antonyms. }\end{array}$} & Experimental & 40 & 2.28 & .679 & \multirow[b]{2}{*}{4.601} & \multirow[b]{2}{*}{78} & \multirow[b]{2}{*}{.05} \\
\hline & Control & 40 & 1.60 & .632 & & & \\
\hline \multirow{2}{*}{$\begin{array}{l}\text { Extracting ideas } \\
\text { written texts. }\end{array}$} & Experimental & 40 & 1.85 & .949 & \multirow[b]{2}{*}{3.549} & \multirow[b]{2}{*}{78} & \multirow[b]{2}{*}{.05} \\
\hline & Control & 40 & 1.25 & .494 & & & \\
\hline \multirow{2}{*}{$\begin{array}{l}\text { Determining general meaning } \\
\text { via read texts }\end{array}$} & Experimental & 40 & 1.73 & .987 & \multirow[b]{2}{*}{1.787} & \multirow[b]{2}{*}{78} & \multirow[b]{2}{*}{.08} \\
\hline & Control & 40 & 1.40 & .591 & & & \\
\hline \multirow{2}{*}{ Total } & Experimental & 40 & 10.45 & 2.375 & \multirow[b]{2}{*}{7.280} & \multirow[b]{2}{*}{78} & \multirow[b]{2}{*}{.05} \\
\hline & Control & 40 & 7.25 & 1.446 & & & \\
\hline
\end{tabular}


Results in Table 2 showed that the experimental group outperformed the control group in all the reading comprehension sub skills. A closer look at table revealed that (recognizing new meanings for one word, recognizing new words for one meaning, classifying words according to synonyms and antonyms, extracting ideas through written texts were the most improved sub skills (i.e. mean $=2.15,2.18,2.28 \& 1.85$ ). On the other hand, Determining general meaning via read texts was the least improved sub skill (mean $=1.73$ ). However, all differences between the experimental and the control group were significant at 0.05 level. This means that the social networks among other variables not measured by this study-was effective in enhancing the students' reading comprehension skills.

\section{Discussion}

Firstly, the researcher has benefitted much from the literature review in carrying out his study in general and especially in building up the study questions, hypotheses, instruments, procedures of the study. As for the first result of this study, which is "there is a statistically significant difference between the mean score of the experimental group (students who were taught by the suggested e-activities via social networks me specifically Facebook) and the mean score of the control group (students who were taught by the regular method) on the overall reading comprehension skills on social networks media post test in favor of the experimental group."

The study asserted the importance of using social networks media for practicing reading in classes of Arabic for Speakers of Other Languages. It also showed the impact of the social networks media, specifically Facebook, in improving the participants' reading comprehension skills.

\section{Suggestions for further research:}

In light of the results of the current study, the researcher suggested the following researches:

1. Applying the suggested e-activities via social networks media to different stages such as primary, secondary and college.

2. Investigating factors that affect the students reading on the social networks media such as; language proficiency, background knowledge, motivation, age and gender.

Analyzing the relation between the students' learning style and their preference for learning on the social networks media. 


\section{References:}

1. Al-Hallaq,A. (2010). Reference in Teaching Arabic Language Skills and Sciences, The Modern Foundation for the Book of Tripoli, Lebanon.

2. Al Mannai, H. \& Everatt, J. (2005). Ponological processing skills as preditors of literacy amongst Arabic speaking Bahraini children. Dyslexia: An International Journal of Research and Practice, 11, 269291.

3. Al-Naqa,M. (1972). The Basic Book of Teaching Arabic Language for Speakers 11, The Institute of Arabic Language, Umm Al-Qura University.

4. Al-Qamati,M. (1986). Sounds and functions. EDUCATION Journal,vol12, 51-55.

5. Aro, M. \& Wimmer, H. (2003). Learning to read: Arabic in comparison to six more regular orthographies. Applied Psycholinguistics, 24, 621-635.

6. Cain, J. (2008). Online social networking issues within academia and language education. American Journal of Education, 7 (1), 10-18.

7. Elian,A. (1990). Linguistic skills and their development methods. Dar Al Musallam:Riyadh.

8. Ellison, N., Steinfield, C.\& Lampe, C. (2007). The benefits of Facebook friends: Social capital and college students' use of online social network sites. Journal of Computed-Mediated Communication, 12 (4), 1143-1168.

9. Hamed, M. (2016). The impact of a proposed web-based unit to enhance Hello! 3 reading comprehension skills for Al-Azhar preparatory institute students. Unpublished master's thesis. Faculty of Education. Mansoura University.

10. Hendrix, D., Chiarella, D., Hasman, L., Murphy, S. \& Zafron, M. (2009). Use of Facebook in academic health sciences libraries. Journal of the educational Library Association, 97 (1), 44-47.

11. Hew, K. (2011). Students' and teachers' use of Facebook. Computers in Human Behaviour, 27 (2), 662-676.

12. Jabal,M. (2017). The effectiveness of activities based on social networks in the development of oral skills among Arabic speakers. Master thesis unpublished. Mansoura University.

13. Kang, Y., Wang, M. J., \& Lin, R. (2008). Usability evaluation of ebooks. Displays, 30 (2), 49-52.

14. Liberman, I., Liberman, A., Mattingly, I. \& Shankweiler, D. (1980). Orthography and the beginning reader. In R.L. Venezky \& Kavanagh, J.F.) Eds. (Orthography, Reading (pp. 137-153). Baltimore, MD: University Park Press. 
15. Madden, J. (2013). Digital disconnect. Record, 118, No. 11, 13-18.

16. Madkour,A. (2006). Teaching Arabic Language Arts. Arab Thought House Cairo.

17. Mayor,A. (2017). The impact of different types of interaction in the social networks (Facebook and Twitter) in the social networks of the 13th scientific conference of the Jordanian Association for Education Technology: Education technology trends and issues contemporary meeting in the period 11-12 / 42012.

18. Mustafa, A. (2007). Arabic Language Skills, DarAlFalah: Amman.

19. Mustafa,A. (1992). Skills of Arabic Language. Dar Al Masirah: Amman.

20. Ortani ,T. (2006). Early intervention measures to prevent reading failure. Arab Journal of Special Education. 8, 147-178.

21. Ponce, B., Fetermann, J., Boohaker, H., Sheppard, E., McGwin, G. Jr \& Theiss, S. (2013). Social networking profiles and professionalism issues in ASOL applicants. Journal of Education, 70 (4), 502-507.

22. Rushdie,T. (1993). Language Skills - Levels, Teaching, Arab Thought House:Cairo.

23. Saiegh-Haddad, E. \& Geva, E. (2008). Morphological awareness phonological awareness, and reading in English-Arabic bilingual children. Reading and Writing: An Interdisciplinary Journal, 21, 481504.

24. Seymour, P., Aro, M. \& Erskine, J. (2003). Foundation literacy skills . British Journal of Psychology, 94, 143-174.

25. Stanovich, K. (2000). Progress in understanding reading: Scientific foundations and new frontiers. New York, N Y: Guilford Press.

26. Thalluri, J.,O'Flaherty J. \& Shepherd P. (2014). Classmate peercoaching: A Study Buddy Support Scheme. Journal of Peer Learning, 7, 92-104.

27. Thompson, L., Dawson, K., Ferdig, R., Black, E., Boyer, J., Coutts, J.\& Black, N. (2008). The intersection of online social networking with language professionalism. Journal of Languages, 23 (7), 954-957.

28. Whittaker,A.,Howarth,G.\&Lymn, K. (2013). Evaluation of Facebook to create an online learning community.Bricks to Bytes, HERGA Conference, p. 99.

29. Wise, L., Skues, J.\&Williams, B. (2011). Facebook in higher education promotes social but not academic engagement. In Changing demands, changing directions. Proceedings Ascilite, [online]. www.ascilite.org. au/conferences/hobart11/downloads/papers/Wisefull.pdf.

30. Zayat,F.(1998).Learning Disabilities: Cairo, Publishing House of Universities. 